\title{
Production of Antimicrobial Substances by Lactobacillus plantarum Immobilized in Calcium Alginate Gel Beads
}

\author{
Onah, D. ${ }^{1}$, Ogbonna, C. N. ${ }^{2}$ and Ogbonna, J. C. ${ }^{1}$ \\ ${ }^{1}$ Department of Microbiology, University of Nigeria, Nsukka. ${ }^{2}$ Department of Plant Science and \\ Biotechnology, University of Nigeria, Nsukka
}

\begin{abstract}
Production of anti-microbial substances by Lactobacillus plantarum, immobilized in calcium alginate gel beads was investigated. The beads were very unstable in De man Rogosa and Sharpe (MRS) medium but the stability of the beads improved by removing potassium and phosphate from the MRS medium. The highest stability of the beads was achieved by addition of calcium chloride to the medium. When $5 \%$ calcium chloride was added to the medium, the stability of the beads increased from 24h (when no calcium chloride was added) to $500 \mathrm{~h}$, without adverse effects on the growth and antimicrobial substance production by the immobilized cells. Although the produced antimicrobial substances inhibited the growth of Bacillus cereus, B. subtilis, Listeria monocytogenes, and Escherichia coli, B. subtilis was the most susceptible. Under all the conditions investigated, immobilization of $L$. plantarum significantly increased the organism's ability to produce antimicrobial substances. Although suspended cells produced higher antimicrobial substances under anaerobic condition, aerobic condition improved antimicrobial substance production by the immobilized cells. This implies that microaerophilic condition is the best for antimicrobial substance production by $L$. plantarum.
\end{abstract}

Keywords: Bio-insecticide, anti-microbial substances, Bacillus thuringiensis, endotoxin Correspondence: james.ogbonna@unn.edu.ng

\section{Introduction}

Lactic acid bacteria (LAB) are the most prominent nonpathogenic bacteria that play vital roles in everyday life ranging from fermentation, preservation and production of wholesome food and vitamins (Udhayashere et. al., 2012). They have been used in food bio-preservation because of their antimicrobial metabolites. These antimicrobial agents include organic acids, hydrogen peroxide, diacetyls and bacteriocin. Bacteriocins are antimicrobial peptides or small protein complex displaying bactericidal activity against food spoilage and food pathogenic organisms. Bacteriocin are ribosomally synthesized peptides produced by various bacteria and exhibit a bacteriostatic or bacteriocidal activity against bacteria that are genetically close relatives (Savadogo et. al., 2006; Yang et. al., 2014).
Although bacteriocins are produced by a broad spectrum of bacteria, those produced by $L A B$ are of particular interest in food industry because these bacteria have generally been recognized as safe (GRAS) organism (Nettles and Barefoot, 1993).

Submerged cultures have been used for most of work on production of bacteriocin and other antimicrobial substances by lactic acid bacteria. However, antimicrobial substances are produced mainly under microaerophilic conditions (MortvedtAbildgaa et. al., 1995); Leal-Sanchez et. al., 2002). Furthermore, efficient production of antimicrobial substances requires high cell concentration which is difficult to achieve in suspended cell cultures. Separation of cells is the first step in purification of antimicrobial substances and this is very expensive in suspended cell cultures 
because of high concentration of free cell in the culture broth.

Immobilization of cells is one of the most attractive methods of maintaining high cell concentration in bioreactors, and thus high volumetric productivity (Ogbonna et. al., 1989a; Dubeya et. al., 2013; Martins et. al., 2013). Furthermore, cell immobilization will reduce or eliminate the need for the separation of cell from the product steam, and the immobilized cells can be used repeatedly for many batches. Among the various methods of cell immobilization, entrapment in ca-alginate has been extensively investigated since the method of immobilization is simple and the immobilization condition is very mild (Ogbonna et. al., 1989a). However, calcium alginate beads are very unstable in fermentation media containing high concentration of phosphate (Ogbonna et. al., 1989b; Kostov et. al., 2010; Fazilah et. al., 2011; Fadel et. al., 2013). The objectives of this research are (a) to immobilize Lactobacillus plantarum in calcium alginate and evaluate the ability of the immobilized cells to produce antimicrobial substances, (b) to evaluate the stability of the immobilized cells during batch cultivation, and (c) to compare their ability to produce antimicrobial substances under aerobic and anaerobic conditions.

\section{Materials and Methods \\ Microorganisms}

Lactobacillus plantarum was used for antimicrobial substance production. It was obtained from the Department of Microbiology, University of Nigeria, Nsukka. Some selected Gram-positive and Gramnegative bacteria associated with food spoilage and food borne diseases were used as target organisms. The microorganisms used were Escherichia coli 11775 obtained from the Bio-resources Development and Conservation Programme (BDCP) Centre, Nsukka. Bacillus cereus, B. subtilis, and Listeria monocytogenes were obtained from the culture collection of the Department of Microbiology, University of Nigeria, Nsukka.

\section{Media and chemicals}

The Lactobacillus plantarum was maintained in De man Rogosa Sharpe (MRS) agar medium (Wako Pure Chemical Industrials Ltd., Osaka Japan) and subcultured every month. MRS broth was used for pre-cultivation while modified MRS broth (mMRS) was used to study the antimicrobial metabolites production by the immobilized cells. The modified MRS was based on component of MRS medium with addition of $\mathrm{CaCl}_{2}$. Nutrient agar was used for screening of bacterial activity of L. plantarum against the target organisms. Sodium alginate was procured from Wako Pure Chemical Industries Ltd. Osaka, Japan. All chemicals and solvents used in the study were of analytical grade and procured from standard firms.

\section{Maintenance of the target organisms}

The target microorganisms were maintained by weekly sub-culturing on tryptic soy broth supplemented with $0.6 \%$ (w/v) yeast extract and $2 \%$ agar slants at $37^{\circ} \mathrm{C}$ for $48 \mathrm{~h}$ and then stored at $4^{\circ} \mathrm{C}$. Before each experiment, the microorganisms were activated by sub-culturing for 24 hour in tryptic soy broth supplemented with $0.6 \%$ $(w / v)$ yeast extract (TSB/YE) under aerobic condition at $37^{\circ} \mathrm{C}$.

\section{Cell immobilization}

The L. plantarum was pre-cultured in MRS broth for $24 \mathrm{~h}$ and the cells were harvested by centrifuging at 3000rpm for $15 \mathrm{~min}$. The cell sediment (pellet) was resuspended in sterile distilled water and a known volume of the cell suspension was added to a $2 \%(w / v)$ solution of sodium alginate to give the desired immobilized cell concentration. The alginate-cell mixture was dropped slowly into a gently stirred $(70 \mathrm{rpm})$ $0.2 \mathrm{M} \mathrm{CaCl}$ solution by micropipette. The alginate solidified upon contact with $\mathrm{CaCl}_{2}$, forming beads entrapping the bacterial cells. The resulting calcium alginate gel beads were incubated in a gently stirred $\mathrm{CaCl}_{2}$ solution for $24 \mathrm{~h}$ to stabilize the beads.

\section{Fermentations}

Production of the antimicrobial substances by both free and immobilized cells were done in 500-ml Erlenmeyer flasks. Each flask, containing $200 \mathrm{ml}$ of MRS medium, was inoculated with the cells and incubated for $48 \mathrm{~h}$ at $37^{\circ} \mathrm{C}$ under static condition. In the case of anaerobic cultures, the flasks were incubated in anaerobic jars maintained at $37^{\circ} \mathrm{C}$. Samples of the culture broth were taken at time intervals and the antimicrobial activities and cell concentrations were assayed using agar well 
diffusion, and plate count methods, respectively.

\section{Beads stability}

The time taken for the beads to dissolve during the fermentation was used to evaluate the chemical stability of the beads. During the fermentation, the beads were monitored visually and the time taken for all the beads in the flask to dissolve was recorded.

\section{Measurement of cell concentrations}

The cell concentrations were determined by cell counting, using pour plate method. For cell concentration in the broth, the broth sample was appropriately diluted and $0.1 \mathrm{ml}$ of the diluted sample was transferred to duplicate sterile Petri dishes. TSB/YE agar medium was poured over the sample in the Petri dishes and mixed by gentle agitation. Plates were incubated for 24 $\mathrm{h}$ at $37^{\circ} \mathrm{C}$ after which the numbers of colonies were counted.

In the case of immobilized cell concentration, calcium alginate gel beads entrapping the cells were dissolved by suspending in $5 \mathrm{ml}$ of $0.2 \mathrm{M}$ citrate buffer and stirring with magnetic stirrer for 30 minutes at room temperature. The caalginate beads dissolved in the citrate buffer and the cell suspension was appropriately diluted. One milliliter sample of the diluted cell suspension was plated on the nutrient agar plates. The plates were then incubated at $37^{\circ} \mathrm{C}$ for $24 \mathrm{~h}$ after which the number of colonies was counted.

\section{Measurement of the antimicrobial activities}

Agar Well Diffusion method was used for assaying antimicrobial activities of the isolates. MRS agar $(20 \mathrm{ml})$ was mixed with $5 \times 10^{8}$ cells $/ \mathrm{ml}$ of a 24-h culture of the indicator microorganism and poured into a Petri-dish. After solidification, wells $(8 \mathrm{~mm}$ in diameter) were made in the agar and filled with $0.1 \mathrm{ml}$ of filtered culture broth of $L$. plantarum. Antimicrobial activities were expressed as the diameter of inhibition zone around the wells after overnight incubation.

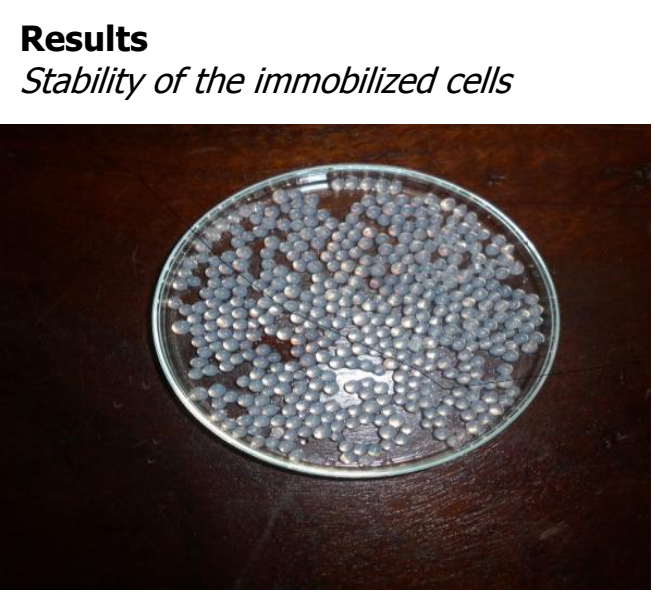

Fig. 1. Alginate gel beads

Figure 1 shows a photograph of the calcium alginate beads immobilizing Lactobacillus plantarum. The beads were all spherical in shape and the sizes of the beads could be varied by extruding the sodium alginate-cell mixtures through nozzles of different diameters. The effects of culture media (De man Rogosa Sharpe Broth (MRS) broth, Tryptone yeast extract and Glucose (TYG) medium, and modified MRS (mMRS) medium) on the stability of the beads were evaluated (Table 1). When the beads were cultivated in MRS broth, they dissolved within $24 \mathrm{~h}$ of incubation. Those cultivated in TYG medium lasted for $48 \mathrm{~h}$ while the beads cultivated in modified MRS medium (without potassium and phosphate) lasted for $72 \mathrm{~h}$. By adding $1 \% \mathrm{CaCl}_{2}$ to MRS medium, the solulization time increased to $72 \mathrm{~h}$. Furthermore, addition of $4 \%$ $\mathrm{CaCl}_{2}$ to the medium prolonged the stability of the beads to $216 \mathrm{~h}$. It is rather surprising that by increasing the $\mathrm{CaCl}_{2}$ concentration from $4 \%$ to $5 \%$, the time taken to solubilize the beads increased sharply from $216 \mathrm{~h}$ to $500 \mathrm{~h}$.

Although addition of $\mathrm{CaCl}_{2}$ significantly increased the stability of the beads, it is necessary to know if addition of $\mathrm{CaCl}_{2}$ has negative effect on cell growth.

Figure 2 shows the number of free (unimmobilized) Lactic Acid Bacteria cells in MRS medium with different concentrations of $\mathrm{CaCl}_{2}$. The amount of cells in the fermentation broth increased as the $\mathrm{CaCl}_{2}$ concentration increased from $1 \%$ to $5 \%$. For instance, at $1 \% \mathrm{CaCl}_{2}$ solution, the number of cells in the culture broth was $2.3 \times 10^{7} \mathrm{cfu} / \mathrm{ml}$ while at $3 \% \mathrm{CaCl}_{2}$, it was $2.5 \times 10^{7} \mathrm{cfu} / \mathrm{ml}$. 
The difference between the cell concentration at $4 \% \mathrm{CaCl}_{2}\left(3.2 \times 10^{7} \mathrm{cfu} / \mathrm{ml}\right)$ and at $5 \% \mathrm{CaCl}_{2}\left(3.3 \times 10^{7} \mathrm{cfu} / \mathrm{ml}\right)$ was not significantly different $(p>0.05)$. The results showed that addition of $\mathrm{CaCl}_{2}$ to the medium has no negative effects on cell growth.

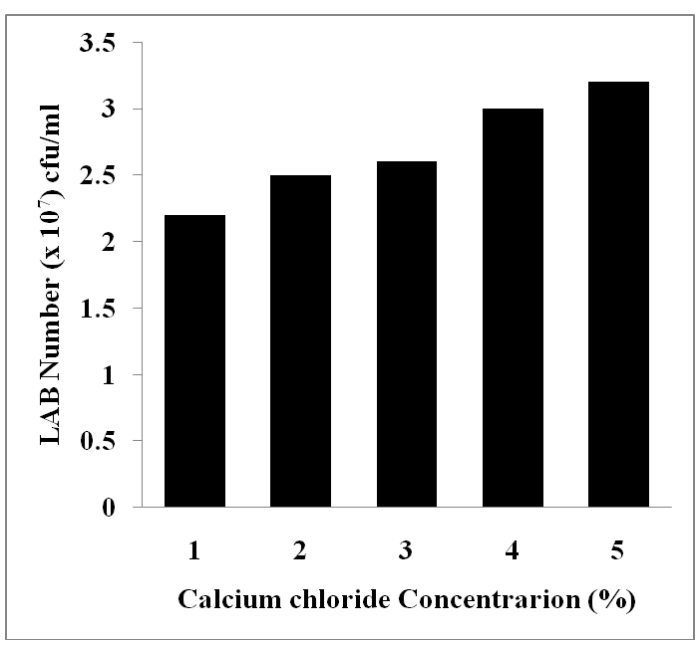

Fig. 2. Effect of addition of different concentration of $\mathrm{CaCl}_{2}$ to medium on cell growth.

Effect of cell immobilization on cell growth and antimicrobial activities

The antimicrobial activities of culture broth obtained from immobilized and free LAB cell cultures against the indicator microorganisms are shown in Figure 3.

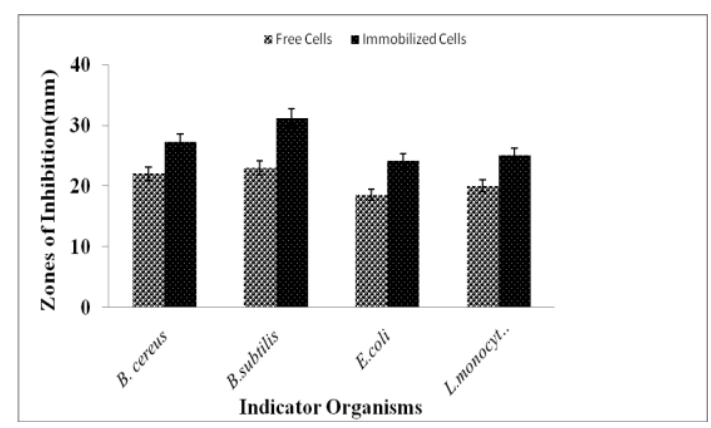

Figure 3. Antimicrobial activity of immobilized and free cells of $L A B$ against indicator organisms

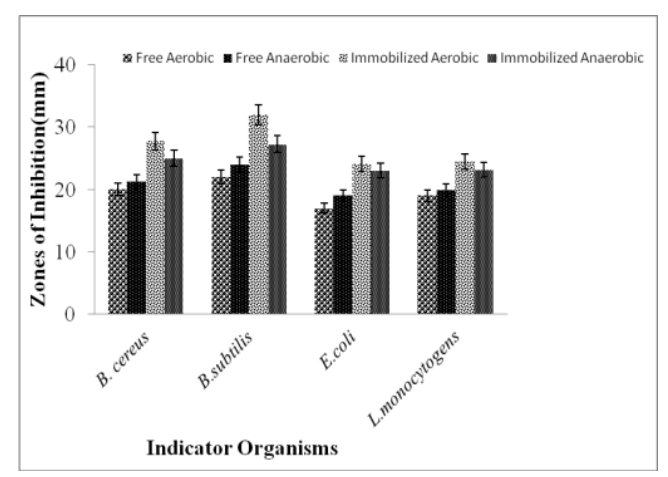

Figure 4. Antimicrobial Activities of Immobilized and Free LAB Cells under Aerobic and Anaerobic.
Statistical analysis indicated that there were significant differences $(p<0.05)$ in the susceptibility of the indicator microorganisms to the inhibitory substances produced by LAB. B. subtilis was the most susceptible, followed by $B$. cereus, while $E$. coli was the least susceptible.

During the cultivation, the amount of cells that leaked out from the beads was $1.0 \times 10^{6} \mathrm{cfu} / \mathrm{ml}$ while the total cell concentration in suspended cell culture was $1.3 \times 10^{7} \mathrm{cfu} / \mathrm{ml}$. This implies that the higher antimicrobial activity in the immobilized cell cultures was due to the immobilized cells rather than the leaked cells.

Effects of oxygen tension on antimicrobial substance production by the immobilized and freely suspended $\angle A B$ cells.

Figure 4 shows the antimicrobial activities of immobilized and free $L A B$ cells under aerobic and anaerobic conditions. Under all the four conditions investigated, $B$. subtilis was the most susceptible, followed by $B$. cereus, while the activities against $E$. coli and $L$. monocytogen were comparable. The immobilized cells produced more antimicrobial substances than the freely suspended cells regardless of whether they were cultivated under aerobic or anaerobic condition.

It is interesting to note that with suspended cell culture, the antimicrobial activities were higher under anaerobic than under aerobic conditions while in the case of immobilized cells, the activities were higher under aerobic than anaerobic conditions. Although data are not shown, it is also important to note that in suspended cell culture, the cell concentrations were higher under anaerobic than under aerobic conditions. A comparison of immobilized cell concentrations under aerobic and anaerobic conditions shows that the immobilized cell concentration under aerobic condition $\left(1.4 \times 10^{10}\right.$ cells/bead) was higher than the cell concentration under anaerobic condition $\left(1.2 \times 10^{10}\right.$ cells/bead).

In all the organisms tested, culture broth from immobilized cell cultures had higher activity against all the indicator microorganisms than the free cell culture $(p<0.05)$. 


\section{Discussion}

This work was designed to improve the production of antimicrobial substances by lactic acid bacteria immobilized in caalginate gel beads and to analyze their inhibitory activities against food spoilage and pathogenic microorganisms. $L A B$ immobilization in ca-alginate gel beads was subjected to different experimental conditions and antimicrobial activities were examined.

The $L$. plantarum was active against $E$. coli ATCC $1175, B$. cereus, B. subtilis and $L$ .monocytogenes. These organisms can contaminate food during processing from varieties of sources, including food handlers and food equipments. They utilize simple compounds in the food and in the process release various volatile off odour components. It has been reported that the shelf life of foods produced by $L A B$ strains showed a relatively better keeping quality (Ogunbawo et. al., 2004, Mills et. al., 2011).

A comprehensive review of the various applications of bacteriocin in various food products including meat, dairy products as well as sea foods was presented by Chen and Hoover (2003), and Bemeda et. al. (2014). The long shelf life of some of the locally fermented foods and condiments such as 'ukpaka' can be attributed to production of antimicrobial substances by the indigenous lactic acid bacteria.

Effect of different media components and $\mathrm{CaCl}_{2}$ concentrations on bead stability showed that MRS medium was unsuitable for cultivation of cells immobilized in calcium alginate. It resulted in the weakening of crosslink in alginate gel beads. Hence, the beads dissolved within 24h. This result is in line with the report of Ogbonna et al.,1989a; Kostov et al., 2010 and Fadel et al., 2013. These reports showed that a medium containing calcium chelating agent such as phosphates or cations (such as $\mathrm{Mg}^{2+}$ or $\mathrm{K}^{+}$) led to disruption of the gel by solubilization of the bound $\mathrm{Ca}^{2+}$. Production of acidic substances may be partly responsible for the disruption of immobilized cells during the fermentation. Addition of $\mathrm{CaCl}_{2}$ to MRS broth increased the stability of the bead during fermentation without any adverse effect on cell growth. This implies that $\mathrm{CaCl}_{2}$ helps to maintain mechanical structure of the alginate beads. This result agrees with reports of Kostov et. al. (2010) and Fadel et. al. (2013) which showed that addition of $\mathrm{CaCl}_{2}$ to medium resulted in solidification and stabilization of the bead. Other factors such as the concentration of sodium alginate, calcium chloride, and cell concentration as well as incubation time affect the stability of the resulting gel beads (Ogbonna et. al., 1989a). Calcium chloride was used as the gelling agent in this work, although the use of Barium chloride as the gelling agent results in higher gel strength (Strand et al., 2000; Bajpai and Sharma, 2004), it is toxic to some cells (Ogbonna et al., 1989b). Calcium was preferred due to concern about possible health and regulatory problems with use of $\mathrm{Br}^{2+}$, especially in food systems.

Immobilized Lactobacillus plantarum had higher activity than the free cells. This suggests that the cell density influenced the metabolism. Pilkington et. al., (1987) confirmed that higher viable cell numbers are reached in immobilized cell fermentation. This might be due to the protection provided by cell immobilization (Champagne et. al., 1994) allowing the cells to overcome some adverse conditions.

The results of the effect of cell immobilization under different conditions showed that immobilized cell culture under aerobic condition had higher antimicrobial activity and higher cell concentration than under anaerobic condition. This suggests that aerobic condition provides conducive environment for production of antimicrobial substances. Batt (1999) and Ray (2000) noted that $L A B$ are microaerophiles and grow best under reduced oxygen tension.

\section{Conclusion}

Lactic acid bacteria produce antimicrobial substances that inhibit the growth of various strains of pathogenic and food spoilage microorganisms. Immobilization of the cells in calcium alginate significantly improved the production of antimicrobial substances by Lactobacillus plantarum. The calcium alginate beads were unstable in MRS medium but the stability was improved by removing phosphate salts from the medium or by adding calcium chloride to the fermentation medium. 
Table 1. Effects of type of media and calcium chloride supplementation on the time taken for the calcium alginate beads to solubilize during cultivation.

\begin{tabular}{ll}
\hline Media & Solubilization time $(\mathrm{h})^{\mathrm{a}}$ \\
\hline De man Rogosa Sharpe (MRS) medium & $24 \pm 1.5$ \\
TYG Medium & $48 \pm 2.2$ \\
MRS medium without Potassium and phosphate & $72 \pm 2.8$ \\
MRS + 1\% calcium chloride & $72 \pm 3.2$ \\
MRS + 2\% calcium chloride & $115 \pm 2.6$ \\
MRS + 3\% calcium chloride & $191 \pm 4$ \\
MRS + 4\% calcium chloride & $216 \pm 4.8$ \\
MRS + 5\% calcium chloride & $500 \pm 15$ \\
\hline
\end{tabular}

a: Solubilization time is the time (h) taken the beads to completely dissolve during cultivation in the medium.

b: TYG medium was composed of $1 \%$ Tryptone, $1 \%$ Yeast extract and $5 \%$ Glucose

\section{References}

Bajpai, S. K. and Sharma, S (2004). Investigation of swelling/degradation behavior of alginate beads cross-linked with $\mathrm{Ca}^{2+}$ and $\mathrm{Ba}^{2+}$ ions. Reactive and functional polymers 59: 129-140.

Batt, C.A. (1999). Lactobacillus: in Robsin, P.D. (eds) Encyclopedia of food microbiology vol.2. Academic press, New York, Pp. 11341151.

Bemeda, L. D., Mohamed, L. A., Fernendes, A. M., and Leel, B. H. (2014). Applications of bacteriocins in food, livestock health and medicine. Int. J. Cur. Microbiol. Appl. Sci. 3(12):924-949.

Champagne, C.P, Gaudy, C., Poncelet, P. and Neufeld, R.T. (1994). Lactococcus lactis release from calcium alginate beads. J. Appl. Environ. Microbiol. 58: 1429-1343.

Chen, H. and Hoover, D. G. (2003). Bacteriocins and their food applications. Comprehensive Rev. Food Sci. and Food Safety. 2: 82-100.

Dubeya, K. K., Jawedb, A., and Haquec, S.(2013). Enhanced bioconversion of colchicine to regiospecific 3-demethylated colchicine (3-DMC) by whole cell immobilization of recombinant $E$. coli harboring P450 BM-3 gene. Process Biochem. 48: 1151-1158.

Fadel, N. F. H., Shamel, M. M. and Zain, M. M. (2013). Mechanical stability of ca-alginate beads as support for yeast cell. EURECA 2013: $101-102$.

Fazilah, A., Maizura. M., Abdkarim, A., Bhupinder, K., Rajeev, B., Uthumporn, U., and Chew, S. H.(2011). Physical and mechanical properties of sago starchalginate film incorporated with calcium chloride. Inter. Food Res. J. 18: 1027-1033.

Kostov, G., Angelov. M., Mihaylov I., and Poncelet D (2010). Mechanical properties of Ca-alginate beads for ethanol fermentation with immobilized yeast. Revue de genie industriel 5: 25-35.

Leal-Shanchez, M. V., Jimenez-Diaz R., Maldonaldo-Barragan, A., Garrido-Fernandez, A., and Ruiz-Barba J. L (2002). Optimization of bacteriocin production by batch fermentation of Lactobacillus plantarum LPCO10. Appl. Environ. Microbiol. 68(9): 4465-4471.

Martins, S. C. S., Martins, C. M., Fiuza. L.M.C.G., and Santaella, S.T.(2013). Immobilization of microbial cells: A promising tool for treatment of toxic pollutants in industrial wastewater. Afri. J. Biotechnol. 12(28): 4412-4418.

Mills, S., Stanton, C., Hill, C., and Ross, RP. (2011). New developments and applications of bacteriocins and peptides in foods. Annu. Rev. Food Sci. Technol. 2: 299-329.

Mortvedt-Abildgaa, C. I., Nissen-Meyer, J., Jelle, B., Grenov, B., Skaugen, M.., and Nes, 
I. F. (1995). Production and pH-dependent bacteriacidal activity of lactocin S, a lantibiotic from Lactobacillus sake L45. Appl. Environ. Microbiol. 61(1): 175-179.

Nettles, C. U and Barefoot, S.F (1993). Biochemical and genetic characteristic of bacteriocins of food association lactic acid bacteria. J. Food Protection. 56: 338-356.

Ogbonna, J.C, Amand, A. and Nakamura, K. (1989a). Elucidation of optimum conditions for immobilization of viable cells by using calcium alginate. J. Ferment. Bioeng. 67: 9296.

Ogbonna J.C., Pham, C.B., Matsumura M. and Kataoka H.(1989b). Evaluation of some gelling agents for immobilization of aerobic microbial cells in alginate and carrageenan gel beads. Biotechnol. Tech., 3, 421-424.

Ogunbawo, S.T., Sanni A.I and Onilude, A.A. (2004). Effect of bacteriocinogenic lactobacillus spp on the self life of fufu, a traditional fermented cassava product. World J. Microbiol. Biotechnol. 20: 57 - 63.

Pilkington, J.B., Shah, R.K., and Dave, J.M. (1987). Survival of Lactobacillus acidophilus in blended spray dried preparations. Australian J. Dairy Technol. 42: 17-21.

Ray, B. (2002). Fundamental food microbiology. $2^{\text {nd }}$ ed CRC press, Boca Ratou London New York Washington DC. P. 113115.

Savadogo, A., Quattara, C.A.T., Bassole, I.H.N., and Traore, S. A. (2006). Bacteriocins and lactic acid bacteria- a minireview. Afr. J. Biotechnol. 5(9): 678 683.

Strand, B. L., Morch, Y. A. and Skjak-Break, G. (2000). Alginate as immobilization matrix for cells. Minerva Biotech. 12: 223-233.

Udhayashere, N., Senbagam, D., Senthikumar, B., Nithya, K., and Gurusamy, R. (2012). Production of bacteriocin and their application in food products. Asian Pacific J. Tropic. Biomed. 2012: S406-S410.

Yang, S. C., Lin, C. H., Sung, C. T., and Fang, J. Y. (2014). Antibaterial activities of bacteriocins: application in foods and pharmaceuticals. Front. Microbiol. 5: 683689. 